\title{
Comparison of transcription of multiple genes during mycelia transition to yeast cells of Paracoccidioides brasiliensis reveals insights to fungal differentiation and pathogenesis
}

\author{
Juliana Alves Parente - Clayton Luiz Borges · Alexandre Melo Bailão • \\ Maria Sueli S. Felipe · Maristela Pereira $\cdot$ Célia Maria de Almeida Soares
}

Received: 12 July 2007 / Accepted: 15 October 2007

(C) Springer Science+Business Media B.V. 2007

\begin{abstract}
The ascomycete Paracoccidioides brasiliensis is a human pathogen with a broad distribution in Latin America. The infection process of $P$. brasiliensis is initiated by aerially dispersed mycelia propagules, which differentiate into the yeast parasitic phase in human lungs. Therefore, the transition to yeast is an initial and fundamental step in the infective process. In order to identify and characterize genes involved in $P$. brasiliensis transition to yeast, which could be potentially associated to early fungal adaptation to the host, expressed sequence tags (ESTs) were examined from a cDNA library, prepared from mycelia ongoing differentiation to yeast cells. In this study, it is presented a screen for a set of genes related to protein synthesis and to protein folding/modification/destination expressed during morphogenesis from mycelium to yeast. Our analysis revealed 43 genes that are
\end{abstract}

Electronic supplementary material The online version of this article (doi:10.1007/s11046-007-9078-8) contains supplementary material, which is available to authorized users.

J. A. Parente - C. L. Borges · A. M. Bailão ·

M. Pereira · C. M. de Almeida Soares $(\square)$

Laboratório de Biologia Molecular, ICB II, Campus II,

Universidade Federal de Goiás, 74001-970 Goiânia,

Goiás, Brazil

e-mail: celia@icb.ufg.br

M. S. S. Felipe

Laboratório de Biologia Molecular, Universidade de

Brasília, Brasília, D.F., Brazil induced during the early transition process, when compared to mycelia. In addition, eight novel genes related to those processes were described in the $P$. brasiliensis transition cDNA library. The types of induced and novel genes in the transition cDNA library highlight some metabolic aspects, such as putative increase in protein synthesis, in protein glycosylation, and in the control of protein folding that seem to be relevant to the fungal transition to the parasitic phase.

Keywords Dimorphic transition .

Induced transcripts - Paracoccidioides brasiliensis . Protein synthesis · Protein folding/modification/ destination

\section{Introduction}

Paracoccidioides brasiliensis is a human pathogen with a broad distribution in Latin America. The fungus is thermally dimorphic. In the soil, the fungus grows as saprobic mycelium and upon elevation of the temperature to that of the mammalian body, the fungus adopts a yeast-like phase [1]. A human host through inhalation acquires the fungal pathogen. The disease, paracoccidioidomycosis, is characterized by a chronic granulomatous inflammation, and patients might present a broad spectrum of clinical manifestations ranging from a localized and benign disease to a progressive and potentially lethal systemic mycosis. 
The severe nature of the disease and occurrence of sequelae, frequently causing pulmonary dysfunction or other disabilities, render it a pathogen of considerable medical importance [2].

$P$. brasiliensis can successfully establish and cause disease, highlighting the need to a better understanding of the molecular mechanisms of pathogenesis. Pathogenicity can be related to the factors associated to the transition from the saprophytic phase to the yeast parasitic phase, since fungal strains that are unable to differentiate into yeast cells are not virulent [3]. In this way, the characterization of genes/proteins related to the differentiation to the parasitic phase may bring insights to the fungal pathogenesis.

The morphological transition in P. brasiliensis is governed predominantly by the temperature and is preceded by several molecular changes. Some biochemical processes related to the dimorphic transition had been elucidated. In this way, the dimorphic transition involves alterations in the cell wall composition and in the structure of carbohydrates polymers [4]. Hyper expression of the enzymes of the sulfur metabolism in the yeast phase during the fungal transition to yeast reinforces previous findings that this metabolic pathway could be important for this differentiation process $[5,6]$. Transcriptional analysis of genes highly expressed during the mycelia to yeast conversion identified the product 4-hydroxylphenyl pyruvate dioxygenase (4-HPPD), predicted to function in the catabolism of aromatic amino acids. Inhibition of 4-HPPD by specific compounds impairs the in vitro differentiation of mycelium to the yeast phase [7]. Also, data indicate that $P$. brasiliensis transition from mycelium to yeast is controlled by changing cAMP levels, with the onset of transition correlating with a transient increase in cAMP, suggesting activation of the cAMP-signaling pathway $[8,9]$.

A number of proteins and genes had been described as potentially associated to the fungal transition and putatively to the host invasion and host fungal survival. Proteomics-based discovery approaches have successfully identified potential candidates to the dimorphic process. Proteomic analysis from mycelium ongoing differentiation to yeast cells was performed allowing the characterization of proteins that could be relevant to the fungal differentiation. In this sense, the proteins HSP70, HSP60, glyceraldehyde-3-phosphate dehydrogenase, catalase $\mathrm{P}$ and actin were accumulated during the transition from mycelium to yeast [10-15].

A great amount of transcriptional data has been obtained from P. brasiliensis [16-21]. Approaches used in this fungus to identify phase-specific genes and or genes important for the dimorphic process, included microarray hybridization approaches [7, 16] and in silico EST subtraction [16]. Transcriptional profiling of microarrays built with ESTs of $P$. brasiliensis has identified 328 genes that are differentially expressed upon the phase transition [16]. In addition, constructed microarrays based on yeast-phase genes and hybridized to RNAs isolated from fungal cells at time points during the switch to the yeast phase enabled the identification of transcripts potentially associated to the fungal morphogenesis [7].

In a previous work, we have tested the concept that novel genes involved in $P$. brasiliensis phase transition could be described by applying a transcriptome analysis of cells undergoing mycelium to yeast transition. We reported the in silico analyses and comparison of ESTs from mycelium undergoing the early transition to yeast with mycelium differentiated cells. According to our data, the developmental program of $P$. brasiliensis is characterized by significant differential positive modulation of transcripts related to cellular processes, predominantly to the cell wall/membrane synthesis/remodeling, suggesting their importance in dimorphism [21].

In this study, in order to advance our understanding on the molecular mechanisms of dimorphic transition and of the initial steps of the fungal adaptation to the host, we sought to examine the profile of transcripts related to protein synthesis/ processing/regulation/degradation in the ESTs generated from the cDNA library of mycelium undergoing transition to yeast cells. Using comparative sequence analyses, we could identify sequences, which were absent in the $P$. brasiliensis yeast and mycelium transcriptome and in public databases, as well as sequences induced during the early fungal transition. Through these approaches, it was found: (1) 54 possible homologues, including 18 induced/novel homologues of genes previously described as related to protein synthesis; and (2) 44 possible homologues, including 25 induced/novel homologues to genes related to protein folding/modification/destination. Those novel/induced genes provide ideal candidates 
for further studies directed at understanding fungal morphogenesis and its regulation.

\section{Materials and methods}

RNA extraction and preparation of the cDNA library

The cDNA library was constructed, as previously reported [21]. Briefly, P. brasiliensis, isolate $P b 01$ (ATCC-MYA-826), was grown in Fava-Netto's medium $[1 \%(\mathrm{w} / \mathrm{v})$ peptone; $0.5 \% \quad(\mathrm{w} / \mathrm{v})$ yeast extract; $0.3 \%(\mathrm{w} / \mathrm{v})$ proteose peptone; $0.5 \%(\mathrm{w} / \mathrm{v})$ beef extract; $0.5 \%(\mathrm{w} / \mathrm{v}) \mathrm{NaCl} ; 4 \%$ (w/v) agar, $\mathrm{pH}$ 7.2], at $22^{\circ} \mathrm{C}$, as mycelium. The differentiation was performed in liquid medium (Fava-Netto's medium) by changing the culture temperature from 22 to $36^{\circ} \mathrm{C}$ for the mycelium to yeast transition, as we previously described [13]. The cells were previously grown in liquid medium for $18 \mathrm{~h}$ before changing the incubation temperature, which was maintained for $22 \mathrm{~h}$.

Total RNA was purified from $P$. brasiliensis mycelium in transition to yeast cells using TRIZOL $\left(\mathrm{GIBCO}^{\mathrm{TM}}\right.$, Invitrogen, Carlsbard, CA). The mRNA was purified by using the Poly (A) Quick ${ }^{\mathrm{R}}$ mRNA isolation kit (Stratagene, La Jola, CA). The cDNA library was constructed in the unidirectional pCMV.SPORT 6 (Invitrogen) according to the manufacturer's instructions, exploiting the NotI and SalI restriction sites. The cDNA library was not normalized, i.e., no attempt was made to reduce the redundancy of highly expressed transcripts.

EST processing pipeline and annotation

The nucleotide sequences were uploaded to a relational database (MySQL) on a Linux (Fedora Core 3) platform, and processed using a modified version of the PHOREST tool [22]. The sequences generated during dimorphic transition of $P$. brasiliensis [21] were compared to sequences generated from yeast and mycelium [16]. Transcripts classification was performed by using the MIPS categorization (http:// www.mips.gsf.de/). Similarities with $E$-values $\leq 10^{-4}$ were considered significant.
In silico determination of induced genes in the mycelium to yeast transition

In order to assign a differential expression character, the contigs formed with mycelium and the transition ESTs were statistically evaluated using the Audic and Claverie's method [23]. It were considered induced genes in the transition library those that were not previously described in the mycelium transcriptome database (http://www.dna.biomol.unb.br/Pb), and those more expressed as determined with a $99 \%$ confidence rate. A web site (http://www.igs.cnrs-mrs. fr/Winflat/winflat.cgi) was used to compute the probability of differential regulation. The $P$. brasiliensis transcriptome database at (http://www.dna. biomol.unb.br/Pb/) and public databases (http://www. ncbi.nlm.nih.gov) were used to identify novel transcripts, by using the BLAST program [24], as described [21].

\section{Results and discussion}

cDNA library sequence annotation

The cDNA library was constructed in a nonnormalized primary library without amplification, so the clone abundance presents the relative mRNA population. The quality of the cDNA library was checked by evaluating the presence of well-characterized transcripts in the MIPS category, such as, those encoding for energy and metabolism. The results of computational homology search of the genes related to protein synthesis/folding/modification/destination obtained from the $P$. brasiliensis mycelium undergoing differentiation to yeast cells are shown in the supplementary material, Tables 1 and 2, respectively. A total of 200 ESTs $(27.3 \%$ of the total transition transcriptome) showed significant similarity to sequences related to protein synthesis/ folding/modification/destination $\left(E\right.$-value $\left.\leq 10^{-4}\right)$ based on BLAST searches. A total of 184 ESTs (25.12\% of the total transition transcriptome) gave significant hits to ESTs present in the P. brasiliensis transcriptome database or in the GenBank database. In addition, 16 ESTs $(2.18 \%$ of the total transition transcriptome) represented novel genes of $P$. brasiliensis regarding to the above processes. 
A broad view of the nature of the adaptations made by $P$. brasiliensis concerning to protein synthesis during early transition to yeast was obtained by classifying the ESTs into 6 groups of functionally related genes (Table 1, supplementary material). Among the transcripts classified in the transition cDNA library and related to protein synthesis, it was found predominantly ESTs coding for ribosomal proteins, comprehending 39 unigenes.

Regarding to protein folding/modification/destination, the ESTs were classified into 6 groups of functionally related genes, as demonstrated in Table 2, supplementary material. Most of the ESTs represent unigenes related to the MIPS classification of posttranslational modification of amino acids (18 unigenes), followed by transcripts related to protein modification by ubiquitination ( 8 unigenes), proteasomal degradation (8 unigenes), protein processing (6 unigenes), and protein folding ( 3 unigenes).

Description of the ESTs related to protein synthesis and fate in the transition transcriptome

As shown in Fig. 1a, the ESTs related to protein synthesis were mainly represented as following: a

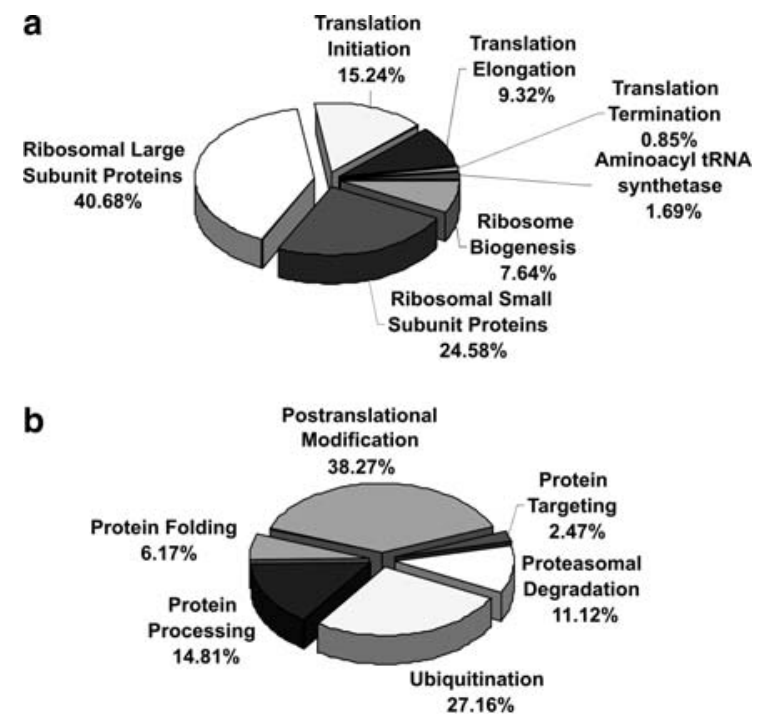

Fig. 1 Distribution of ESTs from P.brasiliensis mycelia ongoing transition to yeast according to their cDNA products. (a) Protein synthesis; (b) protein fate. The classification was based on $E$-value and performed according to the functional categories developed on the MIPS functional annotation scheme. The percentage of ESTs classification is indicated total of $40.68 \%$ of the annotated ESTs corresponded to the ribosomal proteins of the ribosome large subunit; $24.58 \%$ in that category were related to the ribosomal proteins of the ribosome small subunit; $15.24 \%$ of the transcripts corresponded to homologues encoding translational initiation factors; 9.32\% corresponded to ESTs related to the translation elongation machinery. Other ESTs were related to aminoacyl tRNA synthetases (1.69\%), ribosome biogenesis (7.64\%) and translation termination (0.85\%). The Fig. 1b catalogues the ESTs related to protein fate according to the MIPS categories. Most of the transcripts were related to posttranslational modifications of proteins $(38.27 \%)$ and protein ubiquitination $(27.16 \%)$. Transcripts related to protein processing and proteasomal degradation of proteins represented 14.81 and $11.12 \%$, respectively. Classes with lower number of transcripts comprehended those related to protein folding $(6.17 \%)$ and protein targeting $(2.47 \%)$.

High abundant ESTs related to protein synthesis and fate in the transition transcriptome

Table 1 shows the 10 most abundant ESTs related to protein synthesis and folding/modification/destination in the transition transcriptome. The minimum number of ESTs that made up these most highly redundant contigs was 5. Eight out of the ten most abundant ESTs were identified as induced sequences according to the Audic and Claverie's method and one EST represented a novel transcript. Included among the most abundant transcripts were ESTs encoding for proteins related to ribosome assembly/ biogenesis [25-27] and translation [28-30]. Moreover, a transcript encoding a $14 \mathrm{kDa}$ mitochondrial ribosomal protein (mrps14) was detected as a novel transcript. In the $P$. brasiliensis mitochondrial genome, the mrps14 gene was not found [31], suggesting, as described in Arabdopsis thaliana [32] its possible transference to the nucleus.

Also, among the highly redundant transcripts, it was detected homologues of proteins related to the acceleration of the protein folding and ubiquitination in many organisms [33, 34]. Transcript encoding proteins related to stress conditions, such as the homologue of the L-isoaspartate O-methyltransferase (pcmt) that specifically recognizes and methylates 


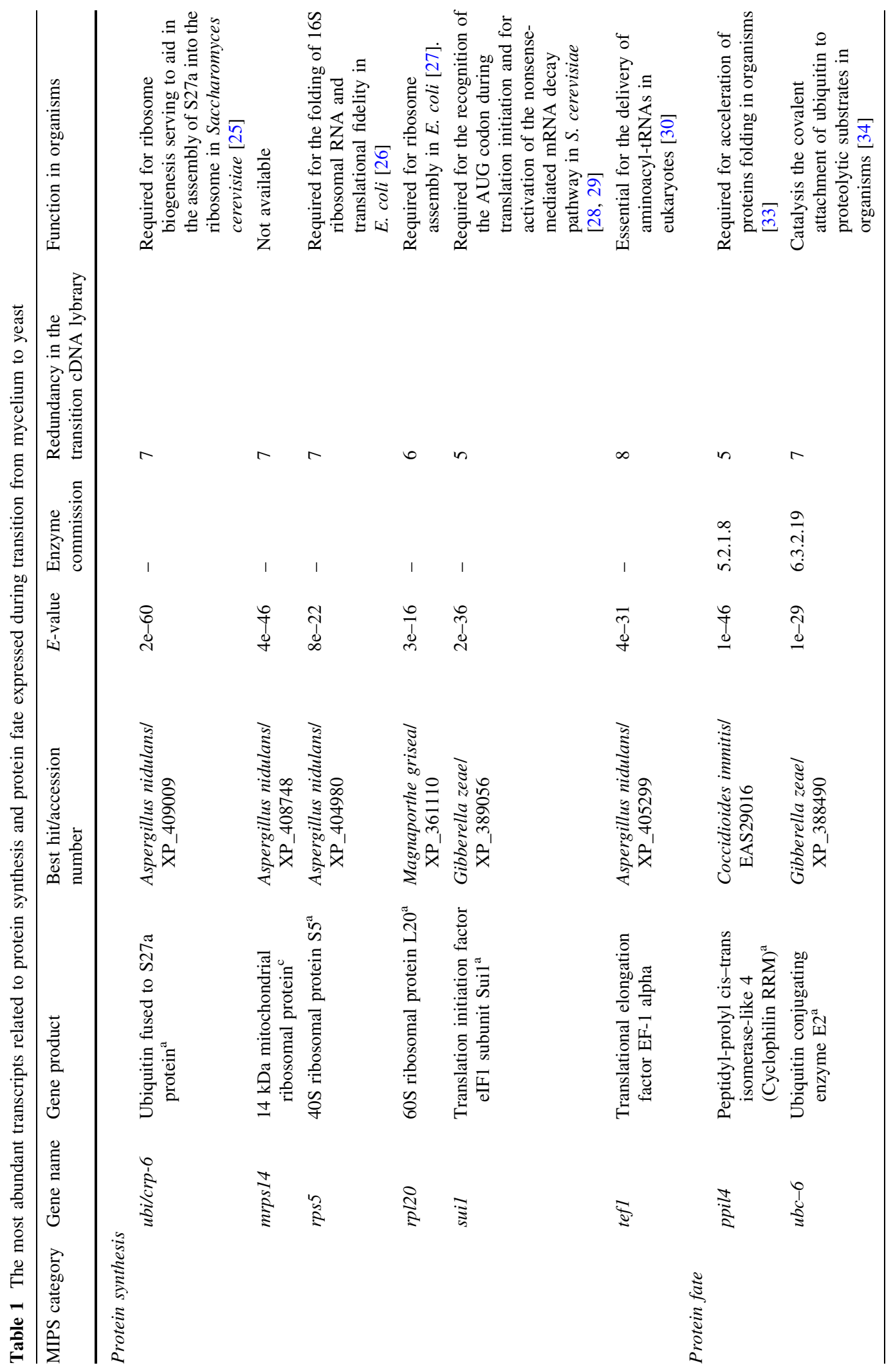




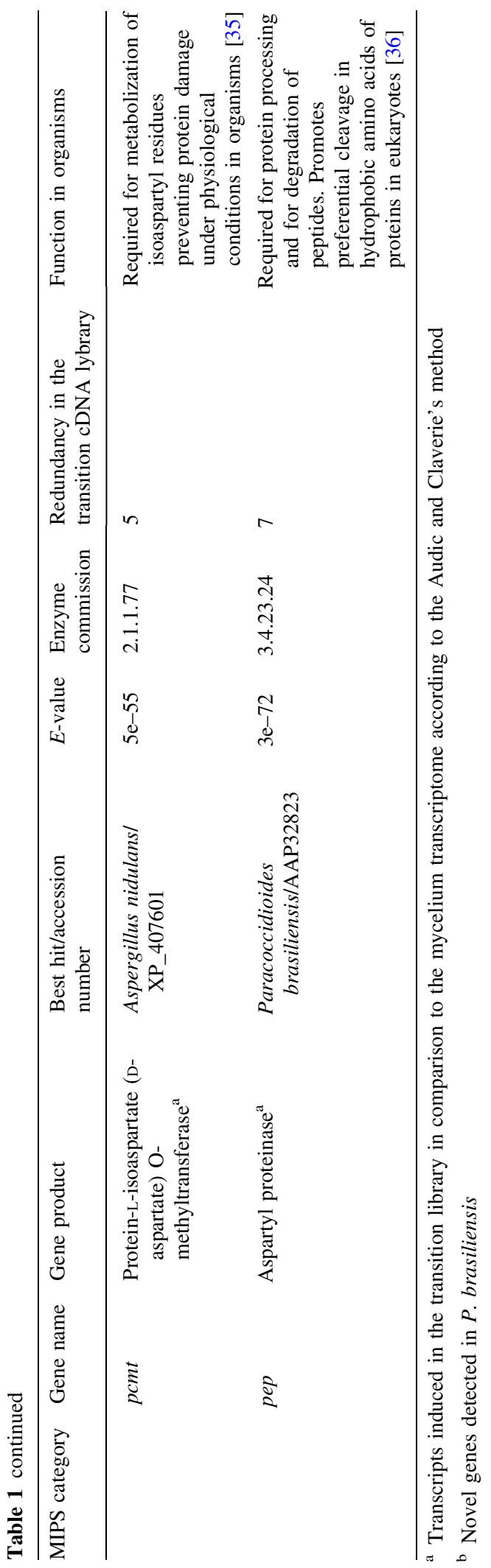

isoaspartyl residues in a variety of proteins [35], thus preventing the accumulation of deamidated proteins under stressing conditions, was high abundant in the morphological transition. Regarding to protein processing, the transcript encoding aspartyl proteinase (pep) was detected. Aspartic proteases are widely distributed in all domains of life and are related to cleavage of peptides in regions of hydrophobic amino acids under acidic conditions. The $S$. cerevisiae vacuolar Pep4p homologue to the $P$. brasiliensis pep product has been described as required for the turnover of damaged molecules during stress conditions [36].

Induced genes related to protein synthesis identified by in silico EST subtraction

We attempted to determine the putative function of the set of 119 phrap unisequences by searching for homologues in the GenBank non-redundant protein database using BLAST $\mathrm{X}$ and by comparing the ESTs in the transition library to those present in the mycelium transcriptome database. The Fig. 2 presents the percentage of induced and novel genes related to protein synthesis in comparison to the total number of ESTs in the transition transcriptome, as described [21]. As observed, from the 119 ESTs related to protein synthesis (10.66\% of the total), $3.97 \%$ were induced in the transition library and $0.9 \%$ was described as novel genes in P. brasiliensis.

The comparative analysis of all the induced ESTs related to protein synthesis in the transition library is available; Table 2 summarizes the results of such comparison. In $P$. brasiliensis, induced transcripts, putatively playing role in ribosomal biogenesis and maturation were detected during dimorphic transition, such as 60S ribosome subunit biogenesis protein (nip7), GTP-binding GTP1/OBG (ygr210) family protein and ubiquitin fused to S27a protein (ubi) crp-6). Proteins composing the small and large ribosomal subunits, as well as translational initiation factors, from both cytoplasmic and mitochondrial ribosomes were over expressed in the transition library; some represent novel genes (Table 2). Similar results were described suggesting that the fungal transition is likely to involve intense synthesis of new ribosome particles, affecting the rate of protein 
ESTs related to protein synthesis and protein

fate of the total number of ESTs in the transition (mycelium to yeast) transcriptome (\%)

Induced ESTs related to protein synthesis and protein fate (\%)

Novel ESTs related to protein synthesis and protein fate (\%)

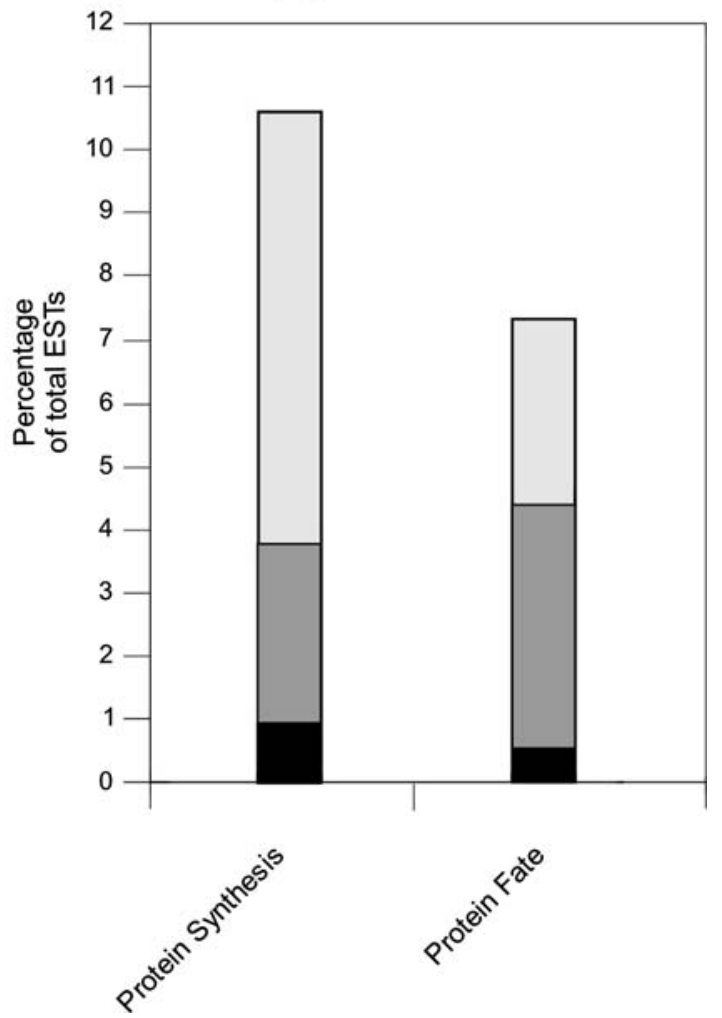

Fig. 2 Prevalence distribution of ESTs from $P$. brasiliensis mycelia ongoing transition to yeast. The percentage of ESTs related to protein synthesis and fate in the total ESTs are represented along with the percentage of over expressed and novel genes of $P$. brasiliensis in the transition library (http://192.168.0.5/phorestwww)

synthesis [7]. In addition, some of the transcripts encode for ribosomal proteins whose orthologues are differentially regulated in organisms. In this sense, the rps 26 product which has no homologue among prokaryotic ribosomal proteins [37] is differentially expressed during environmental stress in plants [38]. Also, the developmental program of organisms seems to include the differential expression of ribosomal proteins; ribosomal protein $r p l 5$ product was specifically identified in schizonts and was undetectable in oocysts in the organism Eimeria tenella [39], suggesting its regulation under different life-cycle stages.
Induced genes related to protein fate identified by in silico EST subtraction: ESTs relevant to protein processing:

We also attempted to determine the putative function of the set of 81 phrap unisequences by searching for homologues in the GenBank non-redundant protein database using BLAST X and by comparing the ESTs in the transition library to those present in the mycelium transcriptome database. The classification of induced genes was designed as described. The Fig. 2 presents the percentage of induced and novel genes related to protein folding/modification/destination in comparison to the total number of ESTs in the transition transcriptome as described [21]. As observed, from the 81 ESTs $(7.32 \%$ of the transition transcriptome), 48 (4.43\% of the total transition transcriptome) were induced in the transition library and $6(0.54 \%)$ were described as novel genes in P. brasiliensis.

The comparative analysis of the ESTs related to protein folding/modification/destination is available; Table 3 summarizes the results of such comparison. A cyclophilin seven suppressor 1 (cnsl) (HSP90 chaperone complex component) was detected. The Hsp90 complex is one of the most abundant and highly conserved chaperone preventing the aggregation of proteins in a folding-competent state and is essential for cell viability in S. cerevisiae [40]. A tailless complex polypeptide 1 chaperonin, subunit epsilon (tcp-1) was also detected. The tcp-1 is localized in the cytosol of higher eukaryotes and is similar to prokaryotes GroEL. The $t c p-1$ product has been related to protein folding in $S$. cerevisiae playing role in cell development and cytoskeletal organization [41]. The two ORFs encoding homologues to the above proteins, presumably reflect the heat shock condition experienced by mycelia in transition to yeast cells.

Glycosyltransferases play vital roles in the biological function of native proteins, as well as, in the biosynthesis of numerous molecules within fungi, including cell wall components and its induced expression putatively reflect the cell wall remodeling that occurs during $P$. brasiliensis morphological transition [4, 21]. The novel/induced genes encode glycosyltransferases that could be related to galactosylation of $\mathrm{N}$-and O-glycans, as described in S. cerevisiae [42]. Mannosyltransferases (och1 and 
Table 2 Novel and over expressed transcripts related to protein synthesis detected during dimorphic transition in $P$. brasiliensis

\begin{tabular}{|c|c|c|c|c|c|c|}
\hline \multirow[t]{2}{*}{ MIPS category } & \multirow{2}{*}{$\begin{array}{l}\text { Gene } \\
\text { name }\end{array}$} & \multirow[t]{2}{*}{ Gene product } & \multirow[t]{2}{*}{ Best hit/accession number } & \multirow[t]{2}{*}{$E$-value } & \multirow{2}{*}{$\begin{array}{l}\text { Enzyme } \\
\text { commission }\end{array}$} & Redundancy $^{\mathrm{d}}$ \\
\hline & & & & & & $\mathrm{M}$ \\
\hline
\end{tabular}

Protein synthesis

Ribosome biogenesis

$\begin{array}{cc}\text { nip7 } & \begin{array}{c}\text { 60S ribosome subunit } \\ \text { biogenesis protein NIP7 }\end{array} \\ \text { ygr210 } & \begin{array}{c}\text { GTP-binding GTP1/OBG } \\ \text { family protein }\end{array} \\ \text { ubi/crp-6 } & \begin{array}{l}\text { Ubiquitin fused to S27a } \\ \text { protein }^{\mathrm{a}}\end{array}\end{array}$

$\begin{array}{lcccc}\begin{array}{l}\text { Aspergillus fumigatus/ } \\ \text { AAM08680 }\end{array} & 3 \mathrm{e}-14 & - & - & 1 \\ \begin{array}{l}\text { Aspergillus nidulans/ } \\ \text { XP_404829 }\end{array} & 1 \mathrm{e}-70 & - & - & 1 \\ \begin{array}{l}\text { Aspergillus nidulans/ } \\ \text { XP_409009 }\end{array} & 2 \mathrm{e}-60 & - & 7 & 7\end{array}$

Ribosomal proteins

Small subunit

$\begin{array}{ll}\text { mrps14 } & \begin{array}{c}\text { 14 } \mathrm{kDa} \text { mitochondrial } \\ \text { ribosomal protein }\end{array} \\ \text { rps13 } & \text { 40S ribosomal protein } \mathrm{S} 13^{\mathrm{b}} \\ \text { rps26 } & \text { 40S ribosomal protein } \mathrm{S} 26^{\mathrm{b}} \\ \text { rps5 } & \text { 40S ribosomal protein } \mathrm{S}^{\mathrm{a}} \\ & \\ \text { mrps19 } & \begin{array}{l}\text { Mitochondrial ribosomal } \\ \text { protein } \mathrm{S} 19^{\mathrm{b}}\end{array}\end{array}$

$\begin{array}{lllll}\text { Aspergillus nidulans/ } & 4 \mathrm{e}-46 & - & - & 7 \\ \text { XP_408748 } & & & & \\ \text { Neurospora crassa/EAA34807 } & 2 \mathrm{e}-37 & - & - & 1 \\ \text { Neurospora crassa/CAA39162 } & 3 \mathrm{e}-52 & - & - & 1 \\ \begin{array}{l}\text { Aspergillus nidulans/ } \\ \text { XP_404980 }\end{array} & 8 \mathrm{e}-22 & - & 8 & 7 \\ \begin{array}{l}\text { Aspergillus nidulans/ } \\ \text { XP_404292 }\end{array} & 5 \mathrm{e}-19 & - & - & 1 \\ & & & & \end{array}$

Large subunit

$\begin{array}{ll}\text { rpl20 } & \text { 60S ribosomal protein } \mathrm{L}^{2} 0^{\mathrm{a}} \\ r p l 27 & 60 \mathrm{~S} \text { ribosomal protein } \mathrm{L}^{2} 7^{\mathrm{a}} \\ r p l 5 & 60 \mathrm{~S} \text { ribosomal protein } \mathrm{L} 2^{\mathrm{b}} \\ r p l 3 & 60 \mathrm{~S} \text { ribosomal protein } \mathrm{L} 3^{\mathrm{a}} \\ r p l 43 & 60 \mathrm{~S} \text { ribosomal protein } \mathrm{L}^{\mathrm{b}} 4 \mathrm{~B}^{\mathrm{b}}\end{array}$
Magnaporthe griseal XP_361110

Aspergillus nidulans/ XP_408359

Coccidioides immitis/ EAS30555

Aspergillus fumigatus/ AAM43909

Translation initiation

Ustilago maydis/XP_400133

$\begin{array}{cccc}3 e-16 & - & 3 & 6 \\ 4 e-63 & - & 1 & 3 \\ 9 e-54 & - & - & 1 \\ 5 e-85 & - & 1 & 2 \\ 1 e-30 & - & - & 1\end{array}$

Translation initiation factor 3
subunit $2^{\mathrm{c}}$
Aspergillus nidulans / XP_660601

eif-5A Translation initiation factor eIF- $5 \mathrm{~A}^{\mathrm{a}}$

- $\quad$ Translational machinery component protein $^{\mathrm{b}}$

suil Translation initiation factor eIF1 subunit Sui1 ${ }^{\mathrm{a}}$

Neurospora crassa/P38672

$6 e-80$

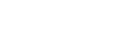
Aspergillus nidulans/ XP_405417

Gibberella zeae/XP_389056

$6 e-06$

$-$

3

$\begin{array}{llll}6 \mathrm{e}-06 & - & 4\end{array}$

$\begin{array}{llll}1 \mathrm{e}-19 & - & - & 1\end{array}$

$2 \mathrm{e}-36-$

25

Aminoacyl-tRNA synthetase

ils1 Isoleucyl-tRNA synthetase $\mathrm{e}^{\mathrm{b}}$

Aspergillus nidulans/

$1 \mathrm{e}-52 \quad 6.1 .1 .5$

2 XP_407499

\footnotetext{
a Transcripts induced in the transition library in comparison to the mycelium transcriptome according to the Audic and Claverie's method

b Transcripts non detected in the mycelia transcriptome (http://www.dna.biomol.unb.br/Pb)

c Novel genes detected in $P$. brasiliensis

${ }^{\mathrm{d}}$ M: Redundancy in P. brasiliensis mycelia transcriptome (http://www.dna.biomol.unb.br/Pb); T: Redundancy in $P$. brasiliensis transition library (http://192.168.0.5/phorestwww/)
} 
Table 3 Novel and over expressed transcripts related to protein fate detected during dimorphic transition in $P$. brasiliensis

\begin{tabular}{lllccc}
\hline MIPS category & $\begin{array}{l}\text { Gene } \\
\text { name }\end{array}$ & Gene product & Best hit/accession number & $\begin{array}{c}E \text {-value } \\
\text { Enzyme } \\
\text { commission }\end{array}$ & $\begin{array}{l}\text { Redundancy } \\
\frac{M}{\mathrm{M}}\end{array}$ \\
\hline
\end{tabular}

Protein fate

Protein folding

$\begin{array}{cl}\text { cns1 } & \text { Cyclophilin seven } \\ & \text { suppressor 1 (HSP90 } \\ & \text { chaperone complex } \\ & \text { component) } \\ & \text { Tailless complex } \\ \text { tcp-1 } & \text { polypeptide } 1 \\ & \text { chaperonin, subunit }^{\text {epsilon }}{ }^{\mathrm{b}}\end{array}$
Aspergillus nidulans/
XP_409575

Schizosaccharomyces pombe/EAA65069

Posttranslational modification of amino acids

\begin{tabular}{|c|c|}
\hline gmal2 & $\begin{array}{l}\text { Alpha-1, 2- } \\
\text { galactosyltransferase }^{\mathrm{c}}\end{array}$ \\
\hline$m n t 1$ & $\begin{array}{l}\text { Alpha-1, 2- } \\
\text { mannosyltransferase }\end{array}$ \\
\hline ochl & Mannosyltransferase $^{\mathrm{b}}$ \\
\hline swpl & $\begin{array}{l}\text { Oligosaccharyltransferase } \\
\text { subunit ribophorin } \text { II }^{\mathrm{d}}\end{array}$ \\
\hline rabggt & $\begin{array}{l}\text { Rab geranylgeranyl } \\
\text { transferase }^{\mathrm{c}}\end{array}$ \\
\hline cypb & $\begin{array}{l}\text { Peptidyl prolyl cis-trans } \\
\text { isomerase }^{\mathrm{b}}\end{array}$ \\
\hline ppill & $\begin{array}{l}\text { Peptidyl-prolyl cis-trans } \\
\text { isomerase-like } 4 \\
\left(_{\text {Cyclophilin RRM })^{\mathrm{a}}}\right.\end{array}$ \\
\hline pcmt & $\begin{array}{l}\text { Protein-L-isoaspartate (D- } \\
\text { aspartate) O- } \\
\text { methyltransferase }^{\mathrm{a}}\end{array}$ \\
\hline gmd1 & Guanosine diphosphatase ${ }^{c}$ \\
\hline
\end{tabular}

Proteasomal degradation

$\begin{array}{lc}\text { rpt6 } & \text { 26S proteasome regulatory } \\ & \text { subunit protein }{ }^{\mathrm{b}} \\ \text { rpn12 } & \text { 26s proteasome regulatory } \\ & \text { subunit rpn12 }{ }^{\mathrm{b}} \\ \text { rpn5; rpne } & \text { 26S proteasome regulatory } \\ & \text { subunit Non-ATPase } \\ \text { csn5 } & \text { COP9 signalosome } \\ & \text { complex subunit } 5^{\mathrm{a}}\end{array}$

Modification by ubiquitination

$\begin{array}{ll}u b p 1 & \begin{array}{l}\text { Ubiquitin-specific protease } \\ (\mathrm{C} 19)^{\mathrm{b}}\end{array} \\ u b c-6 & \begin{array}{l}\text { Ubiquitin conjugating } \\ \text { enzyme E2 }\end{array} \\ & \text { Ubiquitin fusion protein }^{\mathrm{a}}\end{array}$

Aspergillus nidulans/
XP 406106

Neurospora crassal CAC18268

Paracoccidioides brasiliensis/AAK54761

Coccidioides immitis/ EAS29547

Aspergillus nidulans/ XP_412816

Neurospora crassal CAD21421

Coccidioides immitis/ EAS29016

Aspergillus nidulans/ XP_407601
Aspergillus nidulans/ XP_405219

Aspergillus nidulans/

$$
\text { XP_411125 }
$$

Aspergillus nidulans/

$$
\text { XP_407156 }
$$

Aspergillus nidulans/ XP_408912

Aspergillus nidulans/ XP_406266

Aspergillus nidulans/

$$
\text { XP_412211 }
$$

Gibberella zeael XP_388490

Schizosaccharomyces pombe/NP_593923 8e-12 -

$6 e-16$ 2

$\begin{array}{llll}3 \mathrm{e}-14 & 2.4 .1 .- & - & 1 \\ 1 \mathrm{e}-29 & 2.4 .1 .131 & 3 & 3 \\ 3 \mathrm{e}-70 & 2.4 .1 .130 & - & 1 \\ 9 \mathrm{e}-37 & 2.4 .1 .119 & - & 1 \\ 8 \mathrm{e}-13 & 2.5 .1 .60 & - & 1 \\ 8 \mathrm{e}-39 & 5.2 .1 .8 & - & 1 \\ 1 \mathrm{e}-46 & 5.2 .1 .8 & 1 & 5\end{array}$

$\begin{array}{llll}5 e-55 & 2.1 .1 .77 & 4 & 5\end{array}$

$\begin{array}{llll}2 \mathrm{e}-15 & 3.6 .1 .42 \quad-\quad 1\end{array}$

$\begin{array}{llll}4 \mathrm{e}-23 & - & -\end{array}$

$\begin{array}{llll}5 \mathrm{e}-30 & - & - & 1\end{array}$

$\begin{array}{llll}2 \mathrm{e}-68 & - & - & 1\end{array}$

$\begin{array}{llll}1 \mathrm{e}-35 & - & 1 & 2\end{array}$

$7 \mathrm{e}-08 \quad 3.1 .2 .15-3$

$\begin{array}{llll}1 \mathrm{e}-29 & 6.3 .2 .19 & 6 & 7\end{array}$

$\begin{array}{llll}8 \mathrm{e}-67 & - & 3 & 3\end{array}$ 
Table 3 continued

\begin{tabular}{|c|c|c|c|c|c|c|c|}
\hline \multirow[t]{2}{*}{ MIPS category } & \multirow{2}{*}{$\begin{array}{l}\text { Gene } \\
\text { name }\end{array}$} & \multirow[t]{2}{*}{ Gene product } & \multirow[t]{2}{*}{ Best hit/accession number } & \multirow[t]{2}{*}{$E$-value } & \multirow{2}{*}{$\begin{array}{l}\text { Enzyme } \\
\text { commission }\end{array}$} & \multicolumn{2}{|c|}{ Redundancy ${ }^{\mathrm{e}}$} \\
\hline & & & & & & M & $\mathrm{T}$ \\
\hline & ubp1; otub1 & $\begin{array}{l}\text { Ubiquitin thiolesterase } \\
\text { otubain like protein }^{c}\end{array}$ & $\begin{array}{l}\text { Aspergillus nidulans/ } \\
\text { EAA60354 }\end{array}$ & $1 \mathrm{e}-28$ & 3.4.- & - & 1 \\
\hline & $r f n 167$ & $\begin{array}{l}\text { Ring (really interesting new } \\
\text { gene) type zinc finger } \\
\text { (C3HC4) protein (E3 } \\
\text { complex) }^{\text {b }}\end{array}$ & $\begin{array}{c}\text { Schizosaccharomyces } \\
\text { pombe/CAB } 08748\end{array}$ & $5 e-10$ & - & - & 1 \\
\hline & fbl7 & $\begin{array}{l}\text { F-box/LRR-repeat protein } 7 \\
\quad(\mathrm{E} 3 \text { complex })^{\mathrm{b}}\end{array}$ & $\begin{array}{l}\text { Aspergillus nidulans/ } \\
\text { XP_408647 }\end{array}$ & $8 \mathrm{e}-28$ & - & - & 3 \\
\hline \multicolumn{8}{|c|}{ Protein Processing } \\
\hline & pep & Aspartyl proteinase ${ }^{\mathrm{a}}$ & $\begin{array}{l}\text { Paracoccidioides } \\
\quad \text { brasiliensis/AAP32823 }\end{array}$ & $3 e-72$ & 3.4.23.24 & 3 & 7 \\
\hline & lon & Lon protease ${ }^{b}$ & $\begin{array}{l}\text { Pseudomonas fluorescens/ } \\
\text { AF250140_1 }\end{array}$ & $1 \mathrm{e}-05$ & 3.4 .21 .53 & - & 1 \\
\hline & lap & $\begin{array}{l}\text { Peptidase M28 domain } \\
\text { protein }^{\mathrm{c}}\end{array}$ & $\begin{array}{l}\text { Coccidioides immitis/ } \\
\text { EAS33583 }\end{array}$ & $1 \mathrm{e}-22$ & 3.4.11.15 & - & 1 \\
\hline & mde10 & $\begin{array}{l}\text { Zinc metalloprotease } \\
(\mathrm{M} 12)^{\mathrm{b}}\end{array}$ & $\begin{array}{l}\text { Neurospora crassal } \\
\text { CAD } 21161\end{array}$ & $3 e-47$ & 3.4.24.- & - & 1 \\
\hline
\end{tabular}

$\overline{\text { a }}$ Transcripts induced in the transition library in comparison to the mycelium transcriptome according to the Audic and Claverie's method

b Transcripts non detected in the mycelia transcriptome (http://www.dna.biomol.unb.br/Pb)

c Novel genes detected in $P$. brasiliensis

${ }^{\mathrm{d}}$ Genes not described previously in $P$. brasiliensis isolate $P b 01$, but present in public databases

e M: Redundancy in P. brasiliensis mycelia transcriptome (http://www.dna.biomol.unb.br/Pb); T: Redundancy in $P$. brasiliensis transition library (http://192.168.0.5/phorestwww/)

$m n t 1)$ could be putatively related to the $O$-linked mannosylation of proteins, as observed in C. albicans. C. albicans mutants to either mntl or ochl showed hypersensitivity to cell wall perturbing agents, suggesting the proteins role in the cell wall maintenance [43, 44]. Moreover, a novel transcript encoding to guanosine diphosphatase ( $g m d 1$ ) was detected during the dimorphic transition, whose product is known to regulate mannosylation of $\mathrm{N}$ and O-linked oligosaccharides in Golgi complex [45].

Peptidyl-prolyl cis/trans isomerases (cyclophilins) catalyze cis/trans isomerization of a prolyl bond and this isomerization is a time limiting step in folding of certain proteins [46]. Transcripts encoding to two-peptidyl prolyl cis-trans isomerases (cypb and ppil) were induced in $P$. brasiliensis during the transition from mycelium to yeast. Aside from their roles in cellular biochemistry, cyclophylins of microorganisms are particularly interesting since those proteins are found to have a key role in pathogenicity [47]. The $P$. brasiliensis CypB deduced amino acid sequence presents four conserved amino acids: Arg, Phe, Trp and His (RFWH motif, data not shown) described as involved in peptidyl-prolyl cis-trans isomerase activity and related to the activity of the protein in the folding process as described [48].

Protein processing MIPS category is represented by four unigenes induced in $P$. brasiliensis transition library; some presents orthologues with function in stress response and differentiation. The aspartic protease ( $p e p$ ) with seven ESTs, was also included with the most abundant transcripts (see Table 1). The pep product belongs to family A1 of aspartic protease, related to pepsin and synthesized as a propeptide with signal peptide. This peptidase family is related to stress response in S. cerevisiae [36]. The deduced Lon protease (lon) shows homology with family S16, class 001 in MEROPS database (http://www.merops. sanger.ac.uk) and is induced in the transition transcriptome sharing identity with its counterparts in bacteria. The lon product was first identified in E. coli 
Table 4 Homologues for protein synthesis and fate ESTs putatively related to fungal differentiation/virulence or stress tolerance

\begin{tabular}{|c|c|c|c|c|}
\hline \multirow[t]{2}{*}{ Gene product } & \multirow[t]{2}{*}{ Described role } & \multicolumn{2}{|c|}{ Redundancy $^{\mathrm{d}}$} & \multirow[t]{2}{*}{ Reference } \\
\hline & & M & $\mathrm{T}$ & \\
\hline Cyclophilin seven suppressor $1(c n s l)^{\mathrm{b}}$ & $\begin{array}{l}\text { Promotes increase in heat shock response } \\
\text { in Saccharomyces cerevisiae. }\end{array}$ & - & 2 & {$[40]$} \\
\hline Alpha-1, 2-mannosyltransferase $(m n t 1)^{\mathrm{a}}$ & $\begin{array}{l}\text { Required for adhesion and virulence in } \\
\text { Candida albicans }\end{array}$ & 3 & 3 & {$[43]$} \\
\hline Mannosyltransferase $(o c h 1 p)^{\mathrm{b}}$ & $\begin{array}{l}\text { Required for cell wall integrity and } \\
\text { virulence in Candida albicans }\end{array}$ & - & 1 & {$[44]$} \\
\hline Zinc metalloprotease $(m d e 10)^{\mathrm{b}}$ & $\begin{array}{l}\text { Required for spore development in } \\
\text { Schizosaccharomyces pombe }\end{array}$ & - & 1 & {$[52]$} \\
\hline $\begin{array}{l}\text { GTP-binding GTP1/OBG family protein } \\
\quad(y g r 210)^{\mathrm{b}}\end{array}$ & $\begin{array}{l}\text { Involved in regulation of differentiation } \\
\text { in Streptomyces coelicolor. }\end{array}$ & - & 1 & {$[53]$} \\
\hline $\begin{array}{l}\text { Peptidyl prolyl cis-trans isomerase } \\
(\text { cypb })^{\mathrm{b}}\end{array}$ & $\begin{array}{l}\text { Induced in heat shock response in } \\
\text { Aspergillus nidulans. }\end{array}$ & - & 1 & {$[54]$} \\
\hline $\begin{array}{l}\text { Peptidyl-prolyl cis-trans isomerase-like } 4 \\
\quad(\text { ppill })^{\mathrm{a}}\end{array}$ & $\begin{array}{l}\text { Related to thermoresistance in } \\
\text { Paramecium } s p\end{array}$ & 1 & 5 & {$[55]$} \\
\hline Peptidyl-prolyl cis/trans isomerase (ess 1 ) & $\begin{array}{l}\text { Required for Cryptococcus neoformans } \\
\text { virulence }\end{array}$ & 6 & 1 & {$[56]$} \\
\hline Peptidyl-prolyl cis-trans isomerase (mip) & $\begin{array}{l}\text { Required for Legionella pneumophila } \\
\text { survival into macrophages }\end{array}$ & 2 & 2 & {$[57]$} \\
\hline $\begin{array}{l}\text { Protein-L-isoaspartate (D-aspartate) O- } \\
\text { methyltransferase }(p c m t)^{\mathrm{a}, \mathrm{c}}\end{array}$ & $\begin{array}{l}\text { Promotes increase in heat shock survival } \\
\text { in Escherichia coli. }\end{array}$ & 4 & 5 & {$[58]$} \\
\hline Ubiquitin conjugating enzyme E2 $(u b c \sigma)^{\mathrm{a}}$ & $\begin{array}{l}\text { Promotes enhanced in growth of } \\
\text { Saccharomyces cerevisiae at high } \\
\text { temperature. }\end{array}$ & 6 & 7 & {$[59]$} \\
\hline Aspartyl proteinase ${ }^{\mathrm{a}, \mathrm{c}}(p e p)$ & $\begin{array}{l}\text { Secreted by Aspergillus fumigatus during } \\
\text { invasion of the host lung. }\end{array}$ & 3 & 7 & {$[60]$} \\
\hline Lon protease $(l o n)^{\mathrm{b}}$ & $\begin{array}{l}\text { Required for cellular morphology and } \\
\text { virulence in Agrobacterium } \\
\text { tumefaciens }\end{array}$ & - & 1 & {$[61]$} \\
\hline
\end{tabular}

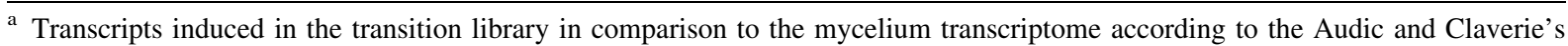
method

b Transcripts non detected in the mycelia transcriptome (http://www.dna.biomol.unb.br/Pb)

c Also over expressed in yeast cells recovered from liver of infected mice (Costa et al. unpublished)

${ }^{\mathrm{d}} \mathrm{M}$ : Redundancy in P. brasiliensis mycelia transcriptome (http://www.dna.biomol.unb.br/Pb); T: Redundancy in P. brasiliensis transition library (http://192.168.0.5/phorestwww/)
}

and its homologues were further discovered in many organisms sometimes in multiple copies, playing essential roles in protein quality control by destroying unfolded proteins [49]. In P. brasiliensis, a gene homologue encoding for a Lon protein of the S16 family, class 002 in MEROPS database (http://www. merops.sanger.ac.uk), was described previously [50], suggesting more than one Lon species in the fungal pathogen. A metalloprotease M28 domain protein (lap) was found as a novel gene in P. brasiliensis, encoding for a leucyl aminopeptidase. In Thichoderma harzianum, the M28 peptidase is induced during nitrogen starvation suggesting its importance in the amino acid acquisition [51]. Other metalloprotease induced in $P$. brasiliensis dimorphic transition is the zinc metalloprotease belonging to M12 family (mde10), whose members were described in fungi [52].

Putative differentiation, virulence and stress tolerance factors

Factors putatively related to the differentiation process, fungal virulence and stress tolerance were 
selected on basis with homology to other microorganisms in which defined functions are available. With these criteria, we classified some transcripts as shown in Table 4. The cns1 product is an essential component of the HSP90 complex, which is induced in heat shock response [40]. Mannosyltransferases (mnt 1 and $o c h 1$ ) orthologues are required for cell wall integrity/virulence and adhesion/virulence, respectively, in C. albicans $[43,44]$. In $S$. pombe, the mde10 product is essential for development of spore envelopes [52] evidencing its importance during differentiation process in the cell. The GTP-binding GTP1/OBG family product (ygr210) related to ribosome biogenesis has been described as a regulator of differentiation in Streptomyces coelicolor, playing a role in the onset of aerial mycelium formation and sporulation [53]. In Aspergillus nidulans, CypB is induced in response to heat shock indicating a possible role of this protein during growth in stress environments [54]. P. tetraurelia KIN241 homologue to peptidyl-prolyl cis-trans isomerase-like 4 (ppill) is related to the organism thermoresistance [55]. A parvulin type Ess1 of Cryptococcus neoformans homologue to $P$. brasiliensis ppil1 product is required for virulence, since Ess1 depleted strains are unable to cause experimental infection [56]. The Mip protein (macrophage infectivity potentiator) of Legionella pneumophila is a cyclophilin FKBP-type homolog which is related to bacterial virulence in intracellular infection in guinea pig [57]. Escherichia coli transformants over expressing L-isoaspartate (D-aspartate) $\mathrm{O}$-methyltransferase presented increase in the heat shock survival rates [58]. Yeast strains over expressing ubiquitin conjugating enzyme E2 are more tolerant to various stresses conditions, such as high temperature [59]. The A. fumigatus aspartyl protease (pep) is highly secreted during fungal invasion of host lung [60]. The Lon protease of Agrobacterium tumefaciens is required for normal growth, cellular morphology and full virulence [61].

\section{Concluding remarks}

Molecular strategies relying on ESTs has proved to be an efficient approach to identify genes expressed under a variety of conditions. This study presents a screen for genes related to protein synthesis/folding/ modification/destination expressed during mycelium to yeast differentiation of $P$. brasiliensis through EST analysis. By analysis of the induced and or novel genes it was possible to infer some metabolic adaptations of $P$. brasiliensis during early dimorphic transition that could include the increased control in the ribosome biogenesis and translation fidelity, increase in protein glycosylation and in the control of protein folding. In addition, the amino acids capture from the medium could be favored during the transition to the parasitic phase.

Acknowledgments This work at Universidade Federal de Goiás was supported by grants from $\mathrm{CNPq}$ (Conselho Nacional de Desenvolvimento Científico e Tecnológico- 505658/20046). Juliana A. Parente and Clayton L. Borges are $\mathrm{PhD}$ fellows from CAPES (Coordenação de Aperfeiçoamento de Pessoal de Nível Superior) and CNPq, respectively.

\section{References}

1. Restrepo A, McEwen JG, Castaneda E. The habitat of Paracoccidioides brasiliensis: how far from solving the riddle? Med Mycol 2001;39:233-41.

2. Franco M, Lacaz C, Restrepo A, Del Negro G, editors. Paracoccidioidomycosis. Boca Ratón: CRC Press, 1994. p. 409.

3. San-Blas G, Ninõ-Vega G. Paracoccidioides brasiliensis: virulence and host response. In: Cihlar RL, Calderone RA, editors. Fungal pathogenesis: principles and clinical applications. New York: Marcel Dekker, 2001.

4. San-Blas G. The cell wall of fungal human pathogens: its possible role in host-parasite relationship. Mycopathologia 1982;79:159-84.

5. Andrade RV, Paes HC, Nicola AM, de Carvalho MJ, Fachin AL, Cardoso RS, Silva SS, Fernandes L, Silva SP, Donadi EA, Sakamoto-Hojo ET, Passos GA, Soares CMA, Brígido MM, Felipe MSS. Cell organization, sulphur metabolism and ion transport-related genes are differentially expressed in Paracoccidioides brasiliensis mycelium and yeast cells. BMC Genomics 2006;7:208.

6. Ferreira ME, Marques Edos R, Malavazi I, Torres I, Restrepo A, Nunes LR, de Oliveira RC, Goldman MH, Goldman GH. Transcriptome analysis and molecular studies on sulfur metabolism in the human pathogenic fungus Paracoccidioides brasiliensis. Mol Genet Genomics 2006;276:450-63.

7. Nunes LR, Costa de Oliveira R, Leite DB, da Silva VS, dos Reis Marques E, da Silva Ferreira ME, Ribeiro DC, de Souza Bernardes LA, Goldman MH, Puccia R, Travassos LR, Batista WL, Nobrega MP, Nobrega FG, Yang DY, de Bragança Pereira CA, Goldman GH. Transcriptome analysis of Paracoccidioides brasiliensis cells undergoing mycelium-to-yeast transition. Eukaryot Cell 2005;12: 2115-28.

8. Paris S, Duran S. Cyclic adenosine $3^{\prime}, 5^{\prime}$ monophosphate (cAMP) and dimorphism in the pathogenic fungus 
Paracoccidioides brasiliensis. Mycopathologia 1985;92: 115-120.

9. Chen D, Janganan TK, Chen G, Marques ER, Kress MR, Goldman GH, Walmsley AR, Borges-Walmsley MI. The cAMP pathway is important for controlling the morphological switch to the pathogenic yeast form of Paracoccidioides brasiliensis. Mol Microbiol 2007;65: 761-79.

10. Da Silva SP, Felipe MSS, Pereira M, Azevedo MO, Soares CMA. Phase transition and stage-specific protein synthesis in the dimorphic fungus Paracoccidioides brasiliensis. Exp Mycol 1994;18:294-9.

11. Salem-Izacc SM, Gomez FJ, Jesuino RSA, Fonseca CA, Felipe MSS, Deepe Jr GS, Soares CMA. Molecular cloning, characterization and expression of the heat shock protein 60 gene from the human pathogenic fungus Paracoccidioides brasiliensis. Med Mycol 2001;39:445-55.

12. Barbosa MS, Cunha Passos DA, Felipe MSS, Jesuíno RS, Pereira M, Soares CMA. The glyceraldehyde-3-phosphate dehydrogenase homologue is differentially regulated in phases of Paracoccidioides brasiliensis: molecular and phylogenetic analysis. Fungal Genet Biol 2004;41:667-75.

13. Moreira SF, Bailão AM, Barbosa MS, Jesuino RS, Felipe MSS, Pereira M, Soares CMA. Monofunctional catalase P of Paracoccidioides brasiliensis: identification, characterization, molecular cloning and expression analysis. Yeast 2004;21:173-82.

14. Da Silva SP, Borges-Walmsley MI, Pereira IS, Soares CMA, Walmsley AR, Felipe MSS. Differential expression of an hsp70 gene during transition from the mycelial to the infective yeast phase of the human pathogenic fungus Paracoccidioides brasiliensis. Mol Microbiol 1999;31: 1039-50.

15. Nino-Vega G, Pérez-Silva C, San-Blas G. The actin gene in Paracoccidioides brasiliensis: organization, expression and phylogenetic analysis. Mycol Res 2007;111:363-9.

16. Felipe MSS, Andrade RV, Arraes FB, Nicola AM, Maranhão AQ, Torres FA, Silva-Pereira I, Poças-Fonseca MJ, Campos EG, Moraes LM, Andrade PA, Tavares AH, Silva SS, Kyaw CM, Souza DP, Pereira M, Jesuíno RS, Andrade EV, Parente JA, Oliveira GS, Barbosa MS, Martins NF, Fachin AL, Cardoso RS, Passos GA, Almeida NF, Walter ME, Soares CMA, Carvalho MJ, Brígido MM. PbGenome network. Transcriptional profiles of the human pathogenic fungus Paracoccidioides brasiliensis in mycelium and yeast cells. J Biol Chem 2005;280:24706-14.

17. Felipe MSS, Andrade RV, Petrofeza SS, Maranhao AQ, Torres FA, Albuquerque P, Arraes FB, Arruda M, Azevedo MO, Baptista AJ, Bataus LA, Borges CL, Campos EG, Cruz MR, Daher BS, Dantas A, Ferreira MA, Ghil GV, Jesuino RS, Kyaw CM, Leitao L, Martins CR, Moraes LM, Neves EO, Nicola AM, Alves ES, Parente JA, Pereira M, Pocas-Fonseca MJ, Resende R, Ribeiro BM, Saldanha RR, Santos SC, Silva-Pereira I, Silva MA, Silveira E, Simoes IC, Soares RB, Souza DP, De-Souza MT, Andrade EV, Xavier MA, Veiga HP, Venancio EJ, Carvalho MJ, Oliveira AG, Inoue MK, Almeida NF, Walter ME, Soares CMA, Brigido MM. Transcriptome characterization of the dimorphic and pathogenic fungus Paracoccidioides brasiliensis by EST analysis. Yeast 2003;20:263-71.
18. Goldman GH, dos Reis Marques E, Duarte Ribeiro DC, de Souza Bernardes LA, Quiapin AC, Vitorelli PM, Savoldi M, Semighini CP, de Oliveira RC, Nunes LR, Travassos LR, Puccia R, Batista WL, Ferreira LE, Moreira JC, Bogossian AP, Tekaia F, Nobrega MP, Nobrega FG, Goldman $\mathrm{MH}$. Expressed sequence tag analysis of the human pathogen Paracoccidioides brasiliensis yeast phase: identification of putative homologues of Candida albicans virulence and pathogenicity genes. Eukaryot Cell 2003;2: $34-48$.

19. Bailão AM, Shrank A, Borges CL, Parente JA, Dutra V, Felipe MSS, Fiúza RB, Pereira M, Soares CMA. The transcriptional profile of Paracoccidioides brasiliensis yeast cells is influenced by human plasma. FEMS Immunol Med Microbiol 2007;51:43-57.

20. Bailão AM, Schrank A, Borges CL, Dutra V, MolinariMadlum EEWI, Felipe MSS, Mendes-Giannini MJS, Martins WS, Pereira M, Soares CMA. Differential gene expression by Paracoccidioides brasiliensis in host interaction conditions: representational difference analysis identifies candidate genes associated with fungal pathogenesis. Microbes Infect 2006;8:2686-97.

21. Bastos KP, Bailão AM, Borges CL, Faria FP, Felipe MSS, Silva MG, Martins WS, Fiuza RB, Pereira M, Soares CMA. The transcriptome analysis of early morphogenesis in Paracoccidioides brasiliensis mycelium reveals novel and induced genes potentially associated to the dimorphic process. BMC Microbiol 2007;7:29.

22. Ahren D, Troein C, Johansson T, Tunlid A. Phorest: a webbased tool for comparative analyses of expressed sequence tag data. Mol Ecol Notes 2004;4:311-4.

23. Audic S, Claverie JM. The significance of digital gene expression profiles. Genome Res 1997;7:986-95.

24. Altschul SF, Madden TL, Schaffer AA, Zhang J, Miller W, Lipman DJ. Gapped BLAST and PSI-BLAST: a new generation of protein database search programs. Nucleic Acids Res 1997;25:3389-402.

25. Finley D, Bartel B, Varshavsky A. The tails of ubiquitin precursors are ribosomal proteins whose fusion to ubiquitin facilitates ribosome biogenesis. Nature 1989;338:394-401.

26. Kirthi N, Roy-Chaudhuri B, Kelley T, Culver GM. A novel single amino acid change in small subunit ribosomal protein S5 has profound effects on translational fidelity. RNA 2006;12:2080-91.

27. Guillier M, Allemand F, Graffe M, Raibaud S, Dardel F, Springer M, Chiaruttini C. The N-terminal extension of Escherichia coli ribosomal protein L20 is important for ribosome assembly, but dispensable for translational feedback control. RNA 2005;11:728-38.

28. Naranda T, MacMillan SE, Donahue TF, Hershey JW. SUI1/p16 is required for the activity of eukaryotic translation initiation factor 3 in Saccharomyces cerevisiae. Mol Cell Biol 1996;16:2307-13.

29. Cui Y, Gonzalez CI, Kinzy TG, Dinman JD, Peltz SW. Mutations in the MOF2/SUI1 gene affect both translation and nonsense-mediated mRNA decay. RNA 1999;5:794804.

30. Browne GJ, Proud CJ. Regulation of peptide-chain elongation in mammalian cells. Eur J Biochem 2002;269:536068. 
31. Cardoso MA, Tambor JH, Nobrega FG. The mitochondrial genome from the thermal dimorphic fungus Paracoccidioides brasiliensis. Yeast 2007;24:607-16.

32. Figueroa P, Gómez I, Carmona R, Holuigue L, Araya A, Jordana $\mathrm{X}$. The gene for mitochondrial ribosomal protein S14 has been transferred to the nucleus in Arabidopsis thaliana. Mol Gen Genet 1999;262:139-44.

33. Fischer G, Tradler T, Zarnt T. The mode of action of peptidyl prolyl cis/trans isomerases in vivo: binding vs. catalysis. FEBS Lett 1998;426:17-20.

34. Sommer T, Jentsch S. A protein translocation defect linked to ubiquitin conjugation at the endoplasmic reticulum. Nature 1993;365:176-9.

35. Clarke S. Propensity for spontaneous succinimide formation from aspartyl and asparaginyl residues in cellular proteins. Int J Pept Protein Res 1987;30:808-21.

36. Marques M, Mojzita D, Amorim MA, Almeida T, Hohmann S, Moradas-Ferreira P, Costa V. The Pep4p vacuolar proteinase contributes to the turnover of oxidized proteins but PEP4 overexpression is not sufficient to increase chronological lifespan in Saccharomyces cerevisiae. Microbiology 2006;152:3595-605.

37. Wool IG, Chan YL, Glueck A. Mammalian ribosomes: the structure and the evolution of the proteins. In: Hershey JWB, Mathews MB, Sonenberg N, editors. Translational control. New York: Cold Spring Harbor Laboratory Press, 1996. p. 685-731.

38. Brosche M, Strid A. The mRNA-binding ribosomal protein S26 as a molecular marker in plants: molecular cloning, sequencing and differential gene expression during environmental stress. Biochim Biophys Acta 1999;1445:342-4.

39. Schaap D, Arts G, van Poppel NF, Vermeulen AN. De novo ribosome biosynthesis is transcriptionally regulated in Eimeria tenella, dependent on its life cycle stage. Mol Biochem Parasitol 2005;139:239-48.

40. Marsh JA, Kalton HM, Gaber RF. Cns1 is an essential protein associated with the hsp90 chaperone complex in Saccharomyces cerevisiae that can restore cyclophilin 40dependent functions in cpr7Delta cells. Mol Cell Biol 1998;18:7353-9.

41. Chen X, Sullivan DS, Huffaker TC. Two yeast genes with similarity to TCP-1 are required for microtubule and actin function in vivo. Proc Natl Acad Sci USA. 1994;91:91115 .

42. Kainuma M, Ishida N, Yoko-o T, Yoshioka S, Takeuchi M, Kawakita M, Jigami Y. Coexpression of alpha1,2 galactosyltransferase and UDP-galactose transporter efficiently galactosylates N- and O-glycans in Saccharomyces cerevisiae. Glycobiology 1999;9:133-41.

43. Munro CA, Bates S, Buurman ET, Hughes HB, Maccallum DM, Bertram G, Atrih A, Ferguson MA, Bain JM, Brand A, Hamilton S, Westwater C, Thomson LM, Brown AJ, Odds FC, Gow NA. Mnt1p and Mnt2p of Candida albicans are partially redundant alpha-1,2-mannosyltransferases that participate in O-linked mannosylation and are required for adhesion and virulence. J Biol Chem 2005;280:1051-60.

44. Bates S, Hughes HB, Munro CA, Thomas WP, MacCallum DM, Bertram G, Atrih A, Ferguson MA, Brown AJ, Odds FC, Gow NA. Outer chain N-glycans are required for cell wall integrity and virulence of Candida albicans. J Biol Chem 2006;281:90-8.

45. Vowels JJ, Payne GS. A role for the lumenal domain in Golgi localization of the Saccharomyces cerevisiae guanosine diphosphatase. Mol Biol Cell 1998;9:1351-65.

46. Tremmel D, Tropschug M. Neurospora crassa FKBP22 is a novel ER chaperone and functionally cooperates with BiP. J Mol Biol 2007;369:55-68.

47. Wang P, Cardenas ME, Cox GM, Perfect JR, Heitman J. Two cyclophilin A homologs with shared and distinct functions important for growth and virulence of Cryptococcus neoformans. EMBO Rep 2001;2:511-8.

48. Bell A, Monaghan P, Page AP. Peptidyl-prolyl cis-trans isomerases (immunophilins) and their roles in parasite biochemistry, host-parasite interaction and antiparasitic drug action. Int J Parasitol 2006;36:261-76.

49. Swamy KH, Goldberg AL. E. coli contains eight soluble proteolytic activities, one being ATP dependent. Nature 1981;292:652-4.

50. Barros TF, Puccia R. Cloning and characterization of a LON gene homologue from the human pathogen Paracoccidioides brasiliensis. Yeast 2001;18:981-8.

51. Suarez MB, Vizcaino JA, Llobell A, Monte E. Characterization of genes encoding novel peptidases in the biocontrol fungus Trichoderma harzianum CECT 2413 using the TrichoEST functional genomics approach. Curr Genet 2007;51:331-42.

52. Nakamura T, Abe H, Hirata A, Shimoda C. ADAM family protein Mde10 is essential for development of spore envelopes in the fission yeast Schizosaccharomyces pombe. Eukaryot Cell 2004;3:27-39.

53. Okamoto S, Ochi K. An essential GTP-binding protein functions as a regulator for differentiation in Streptomyces coelicolor. Mol Microbiol 1998;30:107-19.

54. Joseph JD, Heitman J, Means AR. Molecular cloning and characterization of Aspergillus nidulans cyclophilin B. Fungal Genet Biol 1999;27:55-66.

55. Jerka-Dziadosz M, Garreau de Loubresse N, Beisson J. Development of surface pattern during division in Paramecium. II. Defective spatial control in the mutant kin241. Development 1992;115:319-35.

56. Ren P, Rossettini A, Chaturvedi V, Hanes SD. The Ess 1 prolyl isomerase is dispensable for growth but required for virulence in Cryptococcus neoformans. Microbiology 2005;151:1593-605.

57. Köhler R, Fanghänel J, König B, Lüneberg E, Frosch M, Rahfeld JU, Hilgenfeld R, Fischer G, Hacker J, Steinert M. Biochemical and functional analyses of the Mip protein: influence of the $\mathrm{N}$-terminal half and of peptidylprolyl isomerase activity on the virulence of Legionella pneumophila. Infect Immun 2003;71:4389-97.

58. Kindrachuk J, Parent J, Davies GF, Dinsmore M, AttahPoku S, Napper S. Overexpression of L-isoaspartate Omethyltransferase in Escherichia coli increases heat shock survival by a mechanism independent of methyltransferase activity. J Biol Chem 2003;278:50880-6.

59. Hiraishi H, Mochizuki M, Takagi H. Enhancement of stress tolerance in Saccharomyces cerevisiae by overexpression of ubiquitin ligase Rsp5 and ubiquitin- 
conjugating enzymes. Biosci Biotechnol Biochem 2006; 70:2762-5.

60. Lee JD, Kolattukudy PE. Molecular cloning of the cDNA and gene for an elastinolytic aspartic proteinase from Aspergillus fumigatus and evidence of its secretion by the fungus during invasion of the host lung. Infect Immun 1995;63:3796-803.
61. Su S, Stephens BB, Alexandre G, Farrand SK. Lon protease of the alpha-proteobacterium Agrobacterium tumefaciens is required for normal growth, cellular morphology and full virulence. Microbiology 2006;152:1197-207. 